\title{
The Potential of The Hydroponic Vegetables to Support Food Security in Defense Management Perspective
}

\author{
Fanema Gabrieli ${ }^{1}$, Hikmat Zakky Almubaroq ${ }^{2}$ \\ ${ }^{12}$ Fakultas Manajemen Pertahanan, Universitas Pertahanan Republik Indonesia, Bogor \\ *Corresponding author, e-mail: fanemagabriel@gmail.com
}

\begin{abstract}
In order to support food security, it would be better if the food priority is not only limited to rice, but also supports and optimizes the diversity of technology-based products such as hydroponic vegetables. In Medan City, the hydroponic market was still relatively small. This was seen from the unavailability of hydroponic products sold in various shopping canters. The objective of the study was to identify the internal and external factors in increasing the management of hydroponic vegetables and to formulate the development strategy of hydroponic vegetables in Medan, in order to support food security. The research used a descriptive analytic method by using SWOT, defence management, and food security theory. The samples were taken by using snowball sampling technique. Respondents consisted of several farmers, members of the Hydroponic Community in Medan City (HCM), consumers, officials of the Food Security Agency (BKP) of Medan, and a counsellor from the Agriculture Agency. SWOT matrix analysis of internal and external factors of the Food Security Agency (BKP), Medan showed that the hydroponic vegetables farming development strategy was in quadrant one. The recommended strategy was aggressive strategy which was focused on using strength and opportunity owned by the Food Security Agency (BKP) in order to cope with weakness and threat.
\end{abstract}

Keywords: Development Strategy, Hydroponic, SWOT, Food Security Agency (BKP), Defense Management

Received December 31, $2021 \quad$ Revised January 25, $2022 \quad$ Published Januari 31, 2022

This is an open access article distributed under the Creative Commons 4.0 Attribution License, which permits

unrestricted use, distribution, and reproduction in any medium, provided the original work is properly cited. C2018 by author

\section{Introduction}

The defense adopted by the Indonesian state is a total defense system. The system is essentially a defense involving all citizens in accordance with their roles and functions (Supriyatna, 2017). The defense and security system needs to be carried out by involving components consisting of all national potentials, capabilities, and forces that work in total, integrally, and continuously to realize capabilities in the defense and security of the State. Of course, this also involves the Indonesian agricultural industry.

Indonesia is an agricultural country that prioritizes agricultural products as its largest source of income. The decrease in the area of agricultural land in Indonesia due to the conversion from the agricultural sector to the non-agricultural sector causes agricultural cultivation activities to experience obstacles in providing land. Of course this has a negative impact on increasing the quantity of agricultural production, especially food to meet the needs of the community.

National defence development is executed by orienting towards the integration of national defence, namely military and non-military defence in order to face threats. Indonesia places the National Defence Force (TNI) as the Main Component and is reinforced by a Reserve and Support Component to face military threats. It is capable of facing a non-military threat by placing Ministries and Institutions outside the field of defence as Main Elements assisted by Other National Power Elements. These forces are capable of jointly managing a hybrid threat (Defence Ministry Of The Republic Of Indonesia, 2015). 
An example of a non-military threat is food insecurity. The reduction in agricultural land as a result of rapid population growth and needs as well as reduced human resources for agricultural management are important factors causing reduced food security. Food is one of the basic human needs that must be met every day. Efforts to meet food needs in Indonesia as a developing country are still carried out traditionally, both in agriculture and in the marine sector. Agricultural extensification efforts in Indonesia are carried out through land expansion to meet food quantity so as to achieve food self-sufficiency and national food security. The strategy to achieve food security means ensuring an increase in food availability, food access, and food absorption (Nuh et al., 2020).

In order to face the threat of food insecurity and how to maintain the continuity and sustainability of food, rice is not only the only food priority, but it is necessary to encourage the existence of technology-based food diversity such as hydroponic vegetables. Hydroponics is increasingly being applied in civil society, government and private institutions, as well as educational institutions. Hydroponics is an innovation to improve plant cultivation techniques on narrow areas without the need for soil as a planting medium.

Hydroponics is a very profitable business if carried out seriously. Vegetables from hydroponic cultivation can be used by the community and can create food independence. Hydroponics can be made by various groups in society, both in the community of housewives, youth organizations, and public schools (Madusari et al., 2020).

The development of hydroponics in Indonesia has a good opportunity to fulfill domestic needs and seize export opportunities. Residents of big cities in Indonesia such as Jakarta, Bandung, Surabaya, Medan and other big cities have a tendency to improve their quality of life. The use of quality products provides a sense of comfort for its users. Modern markets are characteristic of the demand for quality products, no longer a lot of products but in fact not guaranteed, but featuring clean products and high continuity.

Especially in Medan, hydroponic vegetables have been widely developed by agribusiness actors, such as Anugrah Farm, Papa Mama Farm, Hidroponikmart Medan and PT. Prosperous hydrotany. The more the same business actors, there will be a competition. So for that we need a strategy to run the farm in order to survive and develop. The company needs to develop its business through a business strategy as a foothold and guide in order to achieve long-term goals (Sitorus, 2020).

However, the distribution of hydroponic products cannot be directly marketed like vegetables in general which are marketed in traditional markets. Nor is it marketed in open stalls. This is because before being marketed and waiting for the distribution process, hydroponic vegetables are stored at room temperature first. These vegetable hydroponic products are usually marketed to supermarkets and hotels. The hydroponic marketing channel starts from hydroponic farmers, then sold to intermediaries or distributors such as markets and finally bought by consumers. It is these distributors who have cooperation contracts with hydroponic entrepreneurs.

In addition, hydroponic vegetables have a higher selling price compared to conventional vegetables. For example, hydroponic lettuce is sold in supermarkets for approximately 35,000 rupiah, but in traditional markets, conventional lettuce is only valued at around 5,000 to 7,000 rupiah. Therefore, the target market segment is generally the middle to upper economic class. Imagine if only 10 percent of the Indonesian population chooses quality and clean products, it means that there are around +25 million people who need hydroponic products every day (Mendrofa, 2017).

In Article 13 of Government Regulation Number 68/2002 concerning regional government and the role of the society in supporting food security. The principle government, the regency/mayoralty government and/or the village government shall be responsible for the organization of food security in their respective territories in compliance with guides, norms, standards, and criteria stipulated by the central government; The principle government, the regency/mayoralty government and/or the village government shall encourage the involvement the society in the organization of food security, can be done through : providing 
of information and educations related to the organization of food security; helping to expedite the organization of food security; improvement of motivation of the society with regard to the organization of food security; improvement of independence of the households in actualizing food security (Government Regulation Of Republic Of Indonesia, 2013).

From a defense management perspective, the potential of hydroponic vegetables can be a solution to support food security. For this reason, it is necessary to develop a marketing management strategy plan and hydroponic vegetable business development. The strategy needs to consider internal and external factors of hydroponic vegetable business in order to increase distribution and interest in hydroponic vegetable cultivation in the society.

\section{Literature Review}

Based on research conducted by Mendrofa (2017) with the title "An Analysis on Marketing Strategy of Hydroponic Vegetables in Medan" shows that the strategy to increase the marketing of hydroponic vegetables by utilizing existing strengths and opportunities is to spur the development of extension workers and optimize government support in utilizing marketing network and online marketing system; Utilize as much as possible, a strategic location for the development of promotions that are fully supported by the government; Optimizing the use of extension workers who have been trained in understanding GAP and SOPs to spur the implementation of GAP and SOPs by producers; Optimizing the experience of producers and utilizing the support of extension workers as much as possible to promote product marketing in various marketing networks. This strategy needs to be carried out in order to maintain the sustainability of the hydroponic vegetable business through the use of government support and the development of extension workers who will help to improve the quality and production and marketing of hydroponic vegetables.

Sinaga \& Chalil (2015) with the title "Analysis of Cut Flower Marketing Strategy (Case Study: Desa Raya, Berastagi District, Karo Regency, North Sumatra Province)" shows that the factors that become strengths are the determination of GAP and SOPs, the development of extension workers. While the weaknesses are the lack of supervision of the implementation of GAP and SOPs, lack of government support, ineffective leaflet, marketing networks that are still regional in scope, and lack of exhibitions. Opportunities that are owned are strategic market locations, high prices received by traders and resellers, high market demand, personal capital, cut flower planting schedules that have seen market share, and good post-harvest management skills. Threats that exist are low selling prices received by farmers, variations in market demand that do not change, and non-implementation of GAP and SOPs in their farming.

Development strategy is a plan to achieve a goal, in its development the concept of strategy must continue to have development and everyone has a different opinion or definition of strategy. Strategy in a business is really needed to achieve the vision and mission that has been implemented by the company, as well as to achieve goals or objectives, both short-term and long-term goals. Business strategy is a strategy that occurs at the product or business unit level and a strategy that emphasizes improving the competitive position of products or services in specific market segments. Functional strategy is a strategy that occurs at the functional level such as, operational, marketing, finance, human resources. Research and development where this strategy will improve the company's functional so that it gets a competitive advantage, this strategy must refer to business strategy and corporate strategy, focusing on maximizing the productivity of the resources used in providing the best value to meet customer needs. Functional strategy is often also called value-based strategy (Sitorus, 2020)

According to Yuwono (2011) marketing is all business efforts so that it can meet the needs of goods and services desired by all consumers. Marketing is a science that examines the physical and economic flow of goods from production through marketing agencies to consumers.

Marketing plays a role in helping to bridge the gap between the needs of producers and consumers. To help producers better understand consumer needs so that producers can do a better job of meeting them. Marketing strategy includes target market, positioning, product line, 
price, distribution, sales force, service quality, advertising, promotion, market research: type and amount (Yuwono, 2011).

The first step that needs to be considered in developing a development strategy is a statement of the company's mission and goals to find out why the company or organization was formed. Then an audit is carried out which aims to find out how well the organization applies its concepts and management. The audit covers the external and internal environment.

The results of the management audit are summarized in the form of a SWOT analysis. SWOT analysis discusses strategic internal and external factors that are strengths and weaknesses as well as opportunities and threats to be faced.

Then, determine the strategic position by combining internal and external factors. Where for the x-coordinate point is obtained from the difference in the weighted score of internal factors, namely strengths and weaknesses, and the y-coordinate point is obtained from the difference in the weighted score of external factors, namely opportunities and threats so as to produce coordinates $(\mathrm{x}, \mathrm{y})$.

The SWOT analysis results in a strategic decision which is a priority to produce a strategy that can be recommended to the Medan City Food Security Agency (BKP) and related parties in improving the management and development of hydroponic vegetables as an effort to support food security.

The Food Security Agency has the task of coordinating and formulating policies in the field of increasing diversification and strengthening food security. In carrying out its duties, the Food Security Agency carries out the following functions: Coordination, assessment, policy formulation, monitoring and stabilization in the field of food availability, reduction of food insecurity, stabilization of food distribution and access to food, diversification of food consumption, and improvement of fresh food safety; Formulation of norms, standards, procedures, and criteria in the field of food availability, reduction of food insecurity, stabilization of food distribution and access to food, diversification of food consumption, and improvement of fresh food safety; Implementation of technical guidance and supervision in the field of food availability, reduction of food insecurity, stabilization of food distribution and access to food, diversification of food consumption, and improvement of fresh food safety; Implementation of evaluation and reporting in the field of food availability, reduction of food insecurity, stabilization of food distribution and access to food, diversification of food consumption, and improvement of fresh food safety; Implementation of the administration of the Food Security Agency; and Implementation of other functions assigned by the Minister (Food Security Agency Ministry of Agriculture, 2022).

RQ: What are the internal and external factors that can improve hydroponic vegetable management opportunities to support food security? What is the hydroponic vegetable business development strategy in the research area?

\section{Method}

The research used a descriptive analytic method using a library research approach. Library research is a study that utilizes library sources to obtain research data, so that in this study library references are the main source (Zed, 2008). The literature review and data sources in this study were obtained by studying various literatures, scientific articles, in the form of books, journals and other documents related to the potential of hydroponic vegetables as a solution and way to support food security.

Data analysis in this study was conducted through a descriptive analysis method, which is defined as an effort to collect and compile data, then analyze the data (Duha et al., 2021). In this case, data on strategic management for the development of hydroponic vegetables in order to support food security were collected from various sources, then the researchers analyzed and interpreted the data through the SWOT analysis method.

Strengths, weaknesses, opportunities and threats (SWOT) analysis is a device that helps business managers to evaluate the strengths, weaknesses, opportunities and threats involved in 
any business enterprise, including farms and ranches. A SWOT analysis can help them gain insights into the past and think of possible solutions to existing or potential problems, either for an existing business or for a new venture. Specifically, SWOT is a basic and candid model that assesses what a business can and cannot do, as well as its potential opportunities and threats. The method of SWOT analysis is to take the information from an environmental analysis and separate it into internal (strengths and weaknesses) and external issues (opportunities and threats). Once this is completed, SWOT analysis determines what may assist the firm in accomplishing its objectives, and what obstacles must be overcome or minimized to achieve the desired results (Ommani, 2011).

\section{Results and Discussion}

The most basic problem in achieving sustainable national food availability as stated by the Ministry of Agriculture is that the production and national food production capacity is increasingly limited; the amount of food demand is increasing along with the increase in population; fulfillment of industrial raw materials and increased use of food in line with the development of tourism, hotels and restaurants; competition in the use of food ingredients for bioenergy and animal feed; food insecurity due to poverty and limited provision of village infrastructure in rural areas; low potential of food resources; decrease in the proportion of food consumption (Sulistyowarni et al., 2017).

\section{Existing Conditions of Strategic Factors}

Internal factors consist of strengths and weaknesses in the marketing of hydroponic vegetables carried out by the Food Security Agency such as; determination of Good Agriculture Practices and Standard Operational Procedures (GAP and SOP), supervision of the implementation of GAP and SOP, government support, guidance for counsellors, leaflets, exhibitions, and research facilities.

Table 1. Determination of Internal Factors

\begin{tabular}{clccl}
\hline No. & \multicolumn{1}{c}{ Description } & $\begin{array}{c}\text { Average } \\
\text { Score }\end{array}$ & $\begin{array}{c}\text { Research } \\
\text { Results }\end{array}$ & $\begin{array}{c}\text { Source of Information } \\
\text { (Person) }\end{array}$ \\
\hline 1 & $\begin{array}{l}\text { Determination of GAP \& } \\
\text { SOP }\end{array}$ & 3 & Strength & BKP and counselor (3) \\
2 & $\begin{array}{l}\text { Supervision of the } \\
\text { implementation of GAP and } \\
\text { SOP }\end{array}$ & 2.3 & Weakness & BKP and counselor (3) \\
3 & Government Support & 4 & Strength & BKP and counselor (3) \\
4 & Guidance for Counselors & 4 & Strength & BKP and counselor (3) \\
5 & Leaflets & 2 & Weakness & BKP and counselor (3) \\
6 & Exhibitions & 2 & Weakness & BKP and counselor (3) \\
7 & Research Facilities & 1 & Weakness & BKP and counselor (3) \\
\hline
\end{tabular}

Source: (Mendrofa, 2017)

Table 1 shows that the results of the assessment of internal factors that affect the marketing of hydroponic vegetables have 3 strengths and 4 weaknesses.

External factors which are opportunities and threats in the marketing of hydroponic vegetables carried out by the Food Security Agency (BKP) of Medan City consist of market location, prices received by farmers, regular customers, implementation of GAP and SOP, 
marketing network, capital, diversity of hydroponic vegetables, schedule planting, post-harvest skills, competitors, experience of producers and the role of farmer associations/institutions.

Table 2. Determination of External Factors

\begin{tabular}{|c|c|c|c|c|}
\hline No. & Description & $\begin{array}{l}\text { Average } \\
\text { Score }\end{array}$ & $\begin{array}{c}\text { Research } \\
\text { Results }\end{array}$ & Source of Information (Person) \\
\hline 1 & Market Location & 3 & Opportunity & Farmers, HCM, Consumers (22) \\
\hline 2 & Prices received by farmers & 3.7 & Opportunity & Farmers and HCM (12) \\
\hline 3 & Regular customers & 2.5 & Threat & Farmers, HCM, Consumers (22) \\
\hline 4 & $\begin{array}{l}\text { Implementation of GAP } \\
\text { and SOP }\end{array}$ & 2.7 & Opportunity & Farmers and HCM (12) \\
\hline 5 & Marketing Network & 2.7 & Opportunity & Farmers and HCM (12) \\
\hline 6 & Capital & 3.7 & Opportunity & Farmers and HCM (12) \\
\hline 7 & $\begin{array}{l}\text { Diversity of Hydroponic } \\
\text { Vegetables }\end{array}$ & 2 & Threat & Farmers, HCM, Consumers (22) \\
\hline 8 & Planting Schedule & 2.3 & Threat & Farmers and HCM (12) \\
\hline 9 & Post-harvest Skills & 3.7 & Opportunity & Farmers and HCM (12) \\
\hline 10 & Competitors & 3.4 & Opportunity & Farmers and HCM (12) \\
\hline 11 & Experience of Producers & 2.8 & Opportunity & Farmers, HCM, Consumers (22) \\
\hline 12 & $\begin{array}{l}\text { The Role of Farmer } \\
\text { Associations/Institutions }\end{array}$ & 2.1 & Threat & Farmers and HCM (12) \\
\hline
\end{tabular}

Source: (Mendrofa, 2017)

Table 2 shows that the results of the assessment of external factors that affect the marketing of hydroponic vegetables have 8 opportunities and 4 threats.

\section{The Development of Hydroponic Vegetables in Strategic Management}

The strategic management process includes four basic elements, namely environmental observation, the management process observing the external environment to see opportunities and threats and observing the internal environment to see strengths and weaknesses; Strategy formulation, development of long-term plans for effective management of environmental opportunities and threats, looking at the company's strengths and weaknesses; Strategy implementation, the process by which management puts its strategies and policies into action through the development of programs, budgets, and procedures; Evaluation and control, the process through which company activities and performance results are monitored and actual performance is compared with the desired work (Syaifullah, 2016).

To determine the right strategy, a hydroponic vegetable marketing evaluation matrix is then carried out by calculating the multiplication between the score and the value on the internal factors which aims to obtain a score (value). The multiplication between scores and value on internal factors in increasing the marketing of hydroponic vegetables is presented in the following table : 
Table 3. Matrix of Internal Strategic Factors Analysis Summary (IFAS)

\begin{tabular}{|c|c|c|c|}
\hline Internal Factors & Value & Score & Score (value) \\
\hline \multicolumn{4}{|l|}{ 1. $\quad$ Strength } \\
\hline A Determination of GAP \& SOP & 0.18 & 3 & 0.54 \\
\hline B Government Support & 0.21 & 4 & 0.84 \\
\hline \multirow{2}{*}{$\begin{array}{r}\text { C Guidance for Counselors } \\
\text { Total }\end{array}$} & 0.13 & 4 & 0.52 \\
\hline & 0.52 & & 1.9 \\
\hline \multicolumn{4}{|l|}{ 2. Weakness } \\
\hline A Supervision of the implementation of GAP and SOP & 0.16 & 2.3 & 0.368 \\
\hline B Leaflets & 0.1 & 2 & 0.2 \\
\hline C Exhibitions & 0.17 & 2 & 0.34 \\
\hline \multirow[t]{3}{*}{ D Research Facilities } & 0.05 & 1 & 0.05 \\
\hline & 0.48 & & 0.958 \\
\hline & & & 0.942 \\
\hline
\end{tabular}

Source: (Mendrofa, 2017)

The result of the highest internal factor score (value) is government support (strength) with a score (value) of 0.84 and supervision of the implementation of GAP and SOP (weakness) with a score (value) of 0.368 . The results of the analysis show that the most dominant influence of internal factors on the increase in marketing of hydroponic vegetables occurs in government support. The existence of government support, especially in the provision of facilities and infrastructure in hydroponic vegetable farming is a good step to increase the marketing of hydroponic vegetables. For example, the government has conducted training through extension workers on the marketing of hydroponic vegetables, but the impact is not too big because the extension's access to marketing is also relatively low.

Currently, the supervision of the implementation of GAP and SOP with a score value of 0.368 , shows that there is still a lack of supervision over the implementation of GAP and SOP by farmers. Hydroponic plant cultivation is not complicated and easy to do. However, supervision is needed, so that vegetables remain of high quality. It can be seen in Table 3 which shows that the difference in the score value of internal strategic factors (strengths-weaknesses) is 0.942 , meaning that the effect of strength is slightly greater than that of weakness in increasing the marketing of hydroponic vegetables.

Then do the multiplication between the score and the value on the external factors to obtain a score value. The multiplication between scores and value on external factors in increasing the marketing of hydroponic vegetables is presented in the following table: 
Table 4. Matrix of Eksternal Factor Analisis Summary (EFAS)

\begin{tabular}{llccc}
\hline \multicolumn{1}{c}{ External Factors } & Value & Score & Score (Value) \\
\hline 1. & Opportunity & & & \\
\hline A & Market Location & 0.0794 & 3 & 0.24 \\
B & Prices received by farmers & 0.0597 & 3.7 & 0.22 \\
C & Capital & 0.0404 & 3.7 & 0.15 \\
D & Post-harvest Skills & 0.0578 & 3.7 & 0.21 \\
E & Competitors & 0.0502 & 3.4 & 0.17 \\
F & Implementation of GAP and SOP & 0.055 & 2.7 & 0.15 \\
G & Marketing Network & 0.1539 & 2.7 & 0.42 \\
I & Experience of Producers & 0.1081 & 2.8 & 0.30 \\
\hline & $\quad$ Total & 0.7163 & & 1.86 \\
\hline 2. & Threat & & & \\
\hline A & Regular customers & 0.1534 & 2.5 & 0.38 \\
B & Diversity of Hydroponic Vegetables & 0.1118 & 2 & 0.22 \\
C & Planting Schedule & 0.076 & 2.3 & 0.17 \\
D & The Role of Farmer Associations/Institutions & 0.0542 & 2.1 & 0.11 \\
\hline & $\quad$ Total & 0.2836 & & $\mathbf{0 . 8 8}$ \\
\hline & $\quad$ (Opportunity \& Threat Score) & & $\mathbf{0 . 9 8}$ \\
\hline Source: (Mendrofa, 2017) & & & \\
\hline
\end{tabular}

The results of the highest value of external factors are network marketing (opportunities) with a score (value) of 0.42 and repeat customers (threats) with a score (value) of 0.38 . Table 4 shows that the difference in the score (value) of external strategic factors (opportunities-threats) is 0.98 , meaning that the effect of opportunity is slightly greater than that of threats in increasing the marketing of hydroponic vegetables. Based on the combination of the evaluation matrix of external and internal factors, it can be seen the strategic position of increasing the marketing of hydroponic vegetables.

The strategic position of increasing the marketing of hydroponic vegetables is analyzed using a position matrix, so as to produce coordinates $(\mathrm{X}, \mathrm{Y})$. The value of $\mathrm{X}$ is obtained from the difference of internal factors and the value of $Y$ is obtained from the difference of external factors. The position of the Cartesian coordinates in Figure 1. 


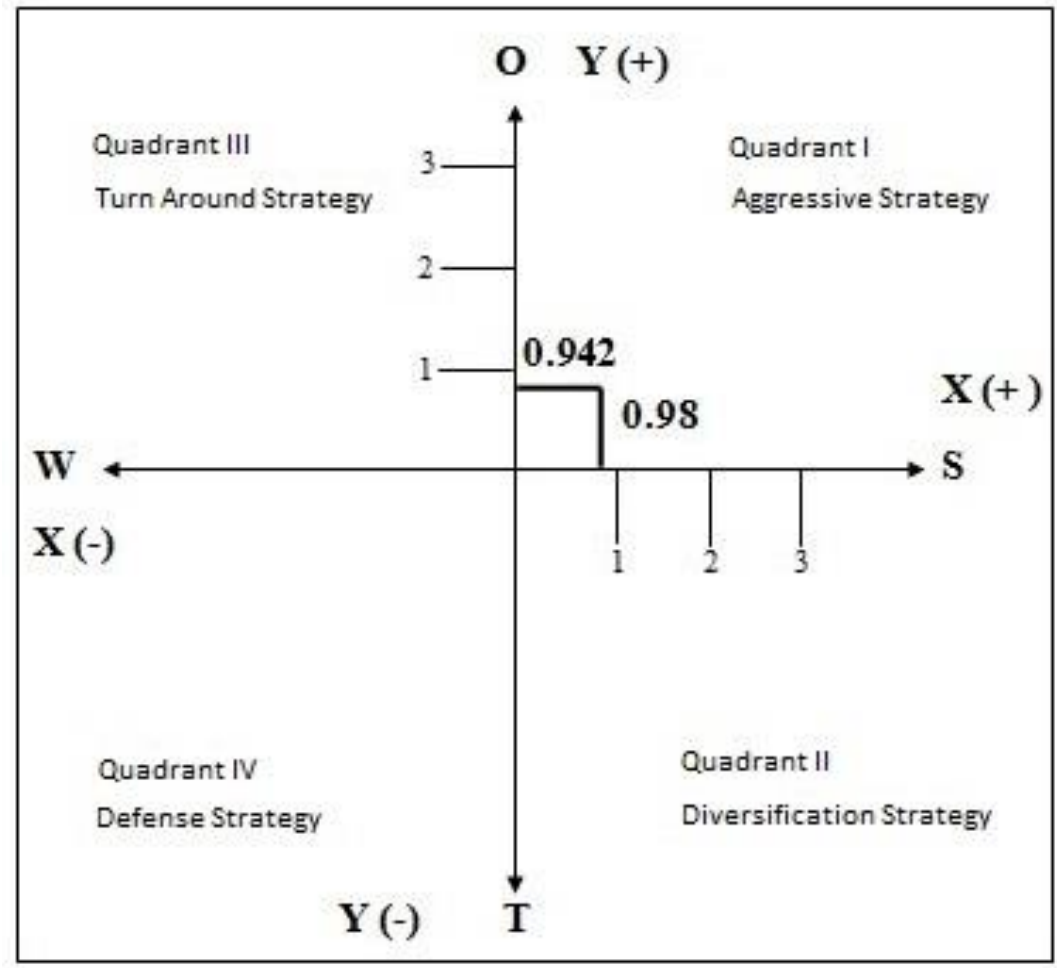

Figure 1. The position of the Cartesian coordinates Source : (Mendrofa, 2017)

Figure 1 shows the value of $\mathrm{X}>0$ which is 0.942 and the value of $\mathrm{Y}>0$ is 0.98 . This means that the position of the strategy to increase the marketing of hydroponic vegetables is in quadrant one which indicates that the strengths of the Medan City Food Security Agency in marketing hydroponic vegetables are greater than weaknesses, and the opportunities they have are greater than the existing threats. The recommended strategy given is an Aggressive Strategy, meaning that it has opportunities and strengths so that it can take advantage of existing opportunities to the fullest. The strategy that must be applied in this condition is to support an aggressive growth policy.

Aggressive strategy, when compared to the role of the Medan City Food Security Agency (BKP) which has been running so far in relation to the marketing of hydroponic vegetables, this strategy is very necessary. This strategy is very important, so that hydroponic marketing grows more. The current BKP strategy is a promotional strategy carried out through exhibitions and leaflets. However, these promotional activities have not been effective, related to the implementation of non-routine exhibitions, as well as in the inadequate provision of leaflets both in terms of the content presented and the number and distribution of leaflets to the public. After determining the marketing strategy of hydroponic vegetables, the aggressive strategy that can be carried out related to the strategy that has been carried out by the Food Security Agency is to take advantage of strategic market locations to hold promotions such as exhibitions and leaflets that are more adequate both in content and quantity.

One of the strategies that can be carried out by the Food Security Agency (BKP) of Medan City is a promotion strategy. BKP already has strengths and opportunities which, if maximized, have the potential to increase the marketing of hydroponic vegetables. For example, aggressive promotion. This means, the marketing network is expanded in various ranges. In addition to online marketing, promotions can also be carried out optimally in the hydroponic market.

\section{Alternative Strategies for Hydroponic Vegetable Improvement and Development}

From the perspective of defense management, the Food Security Agency as one of the government institutions needs to carry out a definite strategy in supporting food security. The 
opportunity for hydroponic vegetables is considered to be one of the effective solutions to overcome food problems in order to prosper the community.

The following is the determination of alternative strategies for developing hydroponic vegetables in the city of Medan presented in table 5 . Based on table 5 below, it shows that the performance of an institution can be determined by a combination of internal and external factors.

Table 5. Determination of Alternative Hydroponic Vegetable Marketing Strategies

\begin{tabular}{|c|c|c|}
\hline EFAS & $\begin{array}{l}\text { Strength } \\
\text { 1. GAP and SOP have been } \\
\text { introduced } \\
\text { 2. Government support } \\
\text { 3. Conselour training is good }\end{array}$ & $\begin{array}{l}\text { Weakness } \\
\text { 1. Supervision of the } \\
\text { implementation of GAP and } \\
\text { SOP is not implemented } \\
\text { 2. Promotion through leaflets is } \\
\text { less effective } \\
\text { 3. Exhibitions are not available } \\
\text { 4. Research facilities are not } \\
\text { available }\end{array}$ \\
\hline $\begin{array}{l}\text { Opportunity } \\
\text { 1. Easy-to-reach market } \\
\text { location } \\
\text { 2. The price received by } \\
\text { farmers is the same as the } \\
\text { price in the market } \\
\text { 3. Good implementation of } \\
\text { GAP and SOP } \\
\text { 4. The marketing network is } \\
\text { quite developed } \\
\text { 5. Personal business capital } \\
\text { 6. Producer experience is } \\
\text { 7. Poite good } \\
\text { 8. Fewer competitors }\end{array}$ & $\begin{array}{l}\text { S-O Strategy } \\
\text { 1. The government supports the } \\
\text { training of counselors in utilizing } \\
\text { market networks and online } \\
\text { marketing systems (S-2, S-3, O- } \\
\text { 4) } \\
\text { 2. Optimization of strategic } \\
\text { locations for promotion } \\
\text { development supported by } \\
\text { government assistance (S-2, O-1) } \\
\text { Maximize trained counselors to } \\
\text { understand GAP and SOP to } \\
\text { support the implementation of } \\
\text { GAP and SOP by producers (S- } \\
\text { 1, S-3, O-3) } \\
\text { 4. Maximize the experience of } \\
\text { producers and take advantage of } \\
\text { counselor support to market } \\
\text { products in various marketing } \\
\text { networks (S-3, O-4, O-6) }\end{array}$ & $\begin{array}{l}\text { W-O Strategy } \\
\text { 1. Promote through leaflets and } \\
\text { exhibitions in strategic market } \\
\text { locations (W-2, W-3, O-1) } \\
\text { 2. Supervise the implementation } \\
\text { of GAP and SOP on a regular } \\
\text { basis so that the } \\
\text { implementation of GAP and } \\
\text { SOP is maximized and post- } \\
\text { harvest skills are getting better } \\
\text { (W-1, O-3, O-7) } \\
\text { 3. Promote by utilizing existing } \\
\text { marketing networks, for } \\
\text { example online flyers (W-2, O- } \\
\text { 4) } \\
\text { 4. Maximize existing capital to } \\
\text { increase promotions by holding } \\
\text { exhibitions (W-2, W-3, O-5) }\end{array}$ \\
\hline $\begin{array}{l}\text { Threats } \\
\text { 1. There are still few regular } \\
\text { customers } \\
\text { 2. Planting schedule does not } \\
\text { follow market share } \\
\text { 3. The role of farmer } \\
\text { associations/institutions is } \\
\text { not good diversity of } \\
\text { 4. The vegetables } \\
\text { hydroponic } \\
\text { marketed is still small }\end{array}$ & $\begin{array}{l}\text { S-T Strategy } \\
\text { 1. The government supports } \\
\text { producers' businesses by helping } \\
\text { to provide more diverse } \\
\text { vegetable seeds (S-2, T-4) } \\
\text { 2. The government supports the } \\
\text { formation of more structured } \\
\text { farmer associations (S-2, T-3) } \\
\text { 3. counselors educate producers so } \\
\text { that they grow vegetables } \\
\text { according to market trends to } \\
\text { meet demand (S-3, T-2) } \\
\text { 4. counselors who have been } \\
\text { trained and understand GAP } \\
\text { and SOPs can apply their }\end{array}$ & $\begin{array}{l}\text { W-T Strategy } \\
\text { 1. Increase exhibition and } \\
\text { promotion activities to expand } \\
\text { marketing to various levels of } \\
\text { society so as to increase } \\
\text { customers (W-2, W-3, T-1) } \\
\text { 2. Increase the role of } \\
\text { associations, so that members } \\
\text { can hold exhibitions more often } \\
\text { to increase customers and } \\
\text { increase demand (W-3, T-1, T- } \\
\text { 3) the rose the role of the } \\
\text { 3. Increase the } \\
\text { association, so that together } \\
\text { they can increase the diversity }\end{array}$ \\
\hline
\end{tabular}




\begin{tabular}{l|l|}
$\begin{array}{l}\text { knowledge so that both } \\
\text { commodities and customers can }\end{array}$ & $\begin{array}{l}\text { of hydroponic vegetables so } \\
\text { that they can increase } \\
\text { improve (S-1, S-3, T-1, T-4) }\end{array}$ \\
& $\begin{array}{l}\text { enthusiasts and customers (T-1, } \\
\text { T-3, T-4) }\end{array}$ \\
\hline
\end{tabular}

\section{S-O Strategy}

This strategy is based on the organization's way of thinking, by optimizing all strengths and using opportunities appropriately. This strategy needs to be carried out in order to maintain the sustainability of the hydroponic vegetable business through the use of government support and the development of extension workers who will help improve the quality and production and marketing of hydroponic vegetables. So that there is a fulfillment of needs and increased food security in the wider community.

\section{W-O Strategy}

This strategy is implemented based on using opportunities by minimizing weaknesses. This strategy also needs to be carried out by the Food Security Agency to utilize capital appropriately, so that it is allocated to increase promotion and marketing by holding exhibitions at market locations.

\section{S-T Strategy}

This is a strategy in using strength factors to overcome threats. Such as government support can create a clear hydroponic vegetable farmer association. So that through the association that has been created, it will be easier for the government to support the marketing of hydroponic vegetables. Therefore, this strategy is needed for long-term opportunities.

\section{W-T Strategy}

The strategy is to monitor weaknesses and threats. For example, by increasing the role of associations, it can increase promotional activities and exhibitions to increase demand and increase marketing of hydroponic vegetables in Medan City.

\section{Conclusions}

Internal factors that affect the increase in the development of hydroponic vegetables, are as follows : the introduction of GAP and SOP, government support, hydroponic plant counselor training has been carried out, there is still a lack of supervision on the implementation of GAP and SOP, leaflets are still ineffective, lack of exhibitions, and research facilities are not available. External factors that affect the increase in hydroponic vegetables are : strategic market location, the price received by farmers is the same as the market price, good GAP and SOP implementation, the marketing network has developed, capital comes from private sources, producer experience is quite good, post-harvest skills is good, competitors few, there are still few regular customers, the variety of hydroponic vegetables is still small, the planting schedule has not followed the market share, and the role of farmer associations/institutions is not good.

Based on the analysis of Strengths, Weaknesses, Opportunities, Threats (SWOT) in increasing the development of hydroponic vegetables, this strategy is in the first quadrant, namely the aggressive strategy. By implementing this strategy, hydroponic vegetables can be an excellent opportunity to overcome non-military threats such as food insecurity. Good management in this field will support food security. Where food security is very important in the context of national development to form quality, independent, and prosperous Indonesian people through the realization of the availability of sufficient, safe, quality, nutritious and diverse food and is evenly distributed throughout Indonesia and affordable by people's purchasing power. 


\section{Acknowledgment}

All praise and gratitude goes to God Almighty because of His mercy, the article entitled The Potential of Hydroponic Vegetables to Support Food Security in Defense Management Perspective (Study in Medan City, Indonesia). The authors also thank the family and lecturers for their support and assistance during the process of writing this article. Hopefully this article can be a useful reference for management stakeholders to support food security in Indonesia.

\section{References}

Defence Ministry Of The Republic Of Indonesia. (2015). Defence White Paper. Ministry Of Defence Of The Republic Of Indonesia. Https://Www.Kemhan.Go.Id/WpContent/Uploads/2016/05/2015-Indonesia-Defence-White-Paper-English-Version.Pdf

Duha, J., Saputro, G. E., \& Purwantoro, S. A. (2021). Marketing Analysis Of Pt . Pindad' S Products In The Era Of The Covid-19 Pandemic In Order To Support The Defense Economy. 4(5), 150-161.

Food Security Agency Ministry Of Agriculture. (2022). Bkp - Tugas Fungsi. Http://Bkp.Pertanian.Go.Id/Tugas-Fungsi

Government Regulation Of Republic Of Indonesia. (2013). Government Regulation Of Republic Of Indonesia Number 68 Of 2013 On The Statute Of Universitas Indonesia.

Madusari, S., Astutik, D., Sutopo, A., Sisi Handini, A., Studi Teknologi Produksi Tanaman Perkebunan, P., Kelapa Sawit Citra Widya Edukasi Jalan Gapura No, P., \& Banteng, R. (2020). Inisiasi Teknologi Hidroponik Guna Mewujudkan Ketahanan Pangan Masyarakat Pesantren. Jurnal Pengabdian Masyarakat Teknik, 2(2), 45-52. Https://Doi.Org/10.24853/Jpmt.2.2.45-52

Mendrofa, F. G. (2017). Analisis Strategi Pemasaran Sayuran Hidroponik Di Kota Medan Skripsi - Pdf Free Download [Universitas Sumatera Utara]. Https://Docplayer.Info/73613388-Analisis-Strategi-Pemasaran-Sayuran-HidroponikDi-Kota-Medan-Skripsi.Html

Nuh, M., Hutasuhut, M. A., \& Ikhsan, M. (2020). Pengembangan Media Tanam Hidroponik Untuk Mendukung Ketahanan Pangan Warga Kecamatan Medan Labuhan. Jurnal Pengabdian Kepada Masyarakat, $26(2), \quad$ 109-114. Https://Doi.Org/10.24114/Jpkm.V26i2.23417

Ommani, A. R. (2011). Strengths, Weaknesses, Opportunities And Threats (Swot) Analysis For Farming System Businesses Management: Case Of Wheat Farmers Of Shadervan District, Shoushtar Township, Iran. African Journal Of Business Management, 5(22), 9448-9454.

Sinaga, S. S., \& Chalil, E. D. (2015). Analisis Strategi Pemasaran Bunga Potong (Studi Kasus : Desa Raya Kecamatan Berastagi Kabupaten Karo Provinsi Sumatera Utara). Journal Of $\begin{array}{llll}\text { Agriculture And Agribusiness } & \text { Socioeconomics, } & \text { 4(8), }\end{array}$ Https://Doi.Org/10.0/Css/All.Css

Sitorus, A. (2020). Strategi Pengembangan Produk Sayur Segar Hidroponik Pt. Hidrotani Sejahtera Kecamatan Sunggal Kabupaten Deli Serdang. Universitas Muhammadiyah Sumatera Utara.

Sulistyowarni, I., Sundari, S., Halim, S., \& Pertahanan, U. (2017). The Potential Of Banana Trading Commodity To Fulfill Market. 3-4.

Supriyatna, A. (2017). Pertahanan Nasional Dalam Perspektif Ekonomi. Unpad Press.

Syaifullah, H. (2016). Identifikasi Perumusan Strategi Pada Pengembangan Usaha Budidaya Sayur Hidroponik. Institut Teknologi Sepuluh Nopember.

JESS, Open Access Journal: http://jess.ppj.unp.ac.id/index.php/JESS 
Yuwono, T. (2011). Pembangunan Pertanian: Membangun Kedaulatan Pangan. Gadjah Mada University Press.

Zed, M. (2008). Metode Penelitian Kepustakaan - Mestika Zed - Google Buku. Yayasan Pustaka Obor Indonesia. Https://Books.Google.Co.Id/Books?Id=Zg9sdaaaqbaj\&Printsec=Frontcover\&H1=Id\# $\mathrm{V}=$ Onepage $\& \mathrm{Q} \& \mathrm{~F}=$ False 